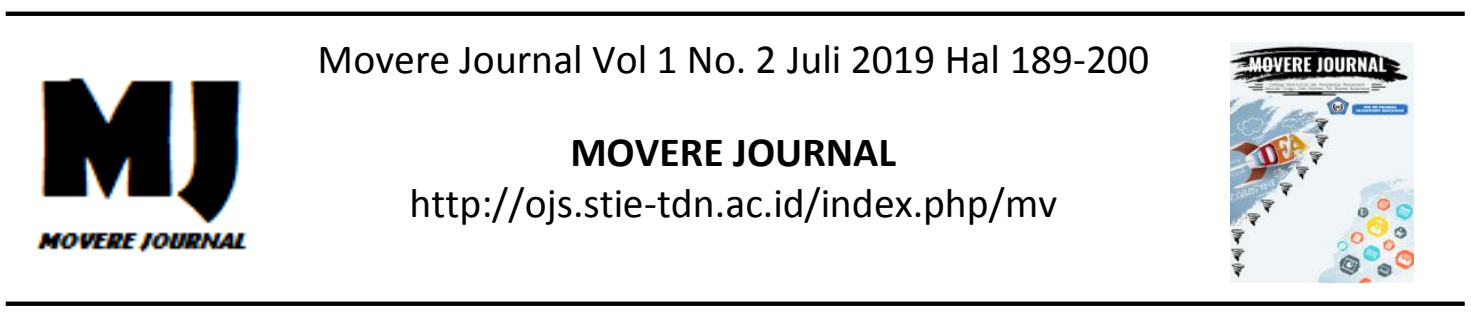

\title{
PENGARUH KUALITAS LAYANAN TERHADAP KEPUASAN PELANGGANG HOTEL ASYRA MAKASSAR
}

\author{
Nyamin Sucipto \\ STIE Tri dharma Nusantara
}

\begin{abstract}
Abstrak : Tujuan penelitian ini untuk mengetahui dan menganalisis pengaruh Kualitas Layanan terhadap Kepuasanan Pelanggang pada Hotel Asyra Makassar. Penelitian ini dilaksanakan di Hotel Asyra Makassar, dengan pertimbangan bahwa data dan informasi yang dibutuhkan mudah diperoleh dan relevan dengan pokok permasalahan. Obyek penelitian ialah Pelanggang Hotel Asyra Makassar. Populasi terdiri keseluruhan Pekanggang yang inap di Hotel Asyra Makassar. Adapun sampel dalam penelitian ini, adalah pelanggang yang inap di Hotel Asyra pada bulan Mei 2019 yang berjumlah 180 pelanggang. Hasil penelitian menunjukkan bahwa (1). kontibusinya terbesar dari kualitas layanan adalah dimensi reliability and trustworthiness, terutama indikator menjadikan nasabah sebagai mitra dan indikator perusahaan selalu memenuhi kewajibannya. Sedangkan yang paling kecil adalah attitudes and behavior, seperti kesiapan petugas dalam membantu saat masuk, inap dan saat keluar hotel dan kesiapan petugas dalam memberi penjelasan ulang tentang hak dan kewajiban pelanggang; (2). Kualitas layanan berpengaruh positif dan signifikan terhadap kepuasan pelanggang pada Hotel Asyra Makassar, dan kontribusi terbesar adalah reliability and trustworthiness.
\end{abstract}

Keyword : Kualitas Layanan, Kepuasan Pelanggan

\section{PENDAHULUAN}

Industri perhotelan mengalami perkembangan yang pesat baik dari segi jumlah hotel yang baru maupun strategi meraup pelanggang, maka para pengelola berupaya mencari strategi pemasaran yang mengacu pada consumer oriented/orietansi kepada pelanggan atau bagaimana memuaskan pelayanan kepada pelanggan. Untuk menciptaan kepuasan pelayanan dibutuhkan suatu citra perusahaan, dan untuk menciptakan kesetiaan konsumen secara berkesinambungan atas pelayanan sebuah hotel maka dibutuhkan kajian secara akurat terhadap citra hotel dan kepuasan pelanggan atau konsumen. Jadi ketiga unsur dari dimensi pemasaran jasa tersebut yaitu citra, kepuasan dan kesetiaan konsumen merupakan suatu sistem yang saling berinteraksi .

Citra hotel dan kepuasan pelanggan merupakan hal yang penting untuk mendapatkan dan memelihara kesetiaan pelanggan. Perusahaan jasa yang memperhatikan kepuasan konsumen akan memperoleh beberapa manfaat, diantaranya yaitu reputasi perusahaan yang semakin positif dimata masyarakat dan pelanggan, dapat mendorong terciptanya loyalitas pelanggan, memungkinkan terciptanya rekomendasi dari mulut ke mulut yang menguntungkan perusahaan, meningkatkan keuntungan dan semakin harmonisnya hubungan perusahaan dengan pelanggan serta

(C) 2019 STIE TDN. All rights reserved 
mendorong anggota organisasi untuk bekerja lebih baik (Tjiptono $2005: 8$ ).

Pelanggan merupakan faktor penting bagi keberhasilan suatu perusahaan dalam menghadapi persaingan yang semakin kompetitif (Bambang: 2001 : 6). Strategi yang didasarkan pada komitmen manajemen untuk meningkatkan kualitas pelayanan yang memuaskan kepada konsumen secara terus menerus dilakukan oleh perusahaan-perusahaan, baik yang menghasilkan produk maupun jasa. Hal ini dilakukan karena kenyataan bahwa konsumen yang tidak loyal terhadap barang atau jasa dari suatu perusahaan sebagai indikasi bahwa produk atau jasa yang ditawarkan tidak memberikan pelayanan memuaskan konsumen atau produk yang tidak berkuaitas.

Kualitas layanan terhadap pelanggan merupakan suatu isu yang sangat menarik dibidang pemasaran. Perusahaan dituntut mampu menawarkan barang atau jasa dengan mutu atau pelayanan yang diberikan pada konsumen dari waktu ke waktu. Pelanggang yang semakin pandai dan terdidik, akan mampu memposisikan perusahaan pada keinginan dan kebutuhan berubah sangat cepat, dimana perusahaan berupaya untuk lebih berorientasi pada konsumen, dengan memberikan kepuasan berupa kualitas layanan pada pelanggang, agar dapat memenagkan persaingan. Dengan memberikan kualitas pada pelanggang akan membangun kesetiaan pelanggang untuk kembali inap dan akhirnya dapat menciptakan hubungan harmonis atau hubungan yang erat antara citra perusahaan dan kesetiaan pelanggang terhadap kualitas layanan dimasa akan datang.

Dewasa ini fungsi hotel telah berkembang jauh seperti adanya penambahan pelayanan pada makanan, minuman/restoran hotel, hiburan, fasilitas yang menarik dan ditambah lagi sebagai tempat dilangsungkannya upacara, konferensi, seminar, rapat dan sebagainya disamping tersedianya sarana untuk menginap yang terus ditingkatkan untuk menambah kepuasan konsumen terhadap hotel tersebut.

Hotel Asyra Makassar adalah hotel bisnis berbintang tiga dengan jumlah kamar 45 terletak di Jalan Maipa No. 1 Makassar. Dalam situasi persaingan hotel yang cukup ketat dewasa ini, Hotel Asyra Makassar berusaha meningkatkan tingkat pelayanan yang lebih memuaskan pelanggan, baik dalam hal kondisi kamar, suguhan makanan atau minuman, keamanan dan unsur dimensi lainnya adalah merupakan salah satu cara meningkatkan kualitas layanan yang diharapkan dapat menciptakan kesetiaan konsumen.

Intensitas persaingan disektor hotel di Makassar yang sangat tinggi, menuntut Hotel Asyraa Makassar agar mampu meningkatkan efektivitas pelayanan yang berkualitas dan memuaskan seluruh pelanggangnya dibandingkan dengan para pesaingnya. Oleh karena kualitas layanan yang baik dan terukur akan meningkatkan citra, kepuasan dan kesetiaan pelanggang terhadap pemakaian jasa Hotel Asyra Makassar adalah merupakan unsurunsur dari dimensi pemasaran jasa yang memerlukan kajian atau evaluasi secara berkesinmbungan guna menjamin kontinuitas dengan tetap mengacu pada konsep orientasi kepada kepuasan pelanggan. Apakah Hotel Asyra selama ini telah mampu mewujudkan kesetian pelanggan atas pelayanan yang diberikan, ataukah masih diperlukan peningkatan manajerial optimalisasi kualitas layanan jasa hotel terhadap kepuasan dan kesetiaan konsumen atas layanan, sebagai suatu sistem yang memerlukan pendekatan konsep manajemen pemasaran secara akurat. 
Berdasarkan latar belakang tersebut diatas, maka dilakukan penelitian dengan kajian konsep manajemen pemasaran dengan judul : "Pengaruh Kualitas Layanan terhadap Kepuasan Pelanggang Hotel Asyra Makassar".

Berdasarkan latar belakang penelitian di atas, maka rumusan masalah yang dapat dikemukakan dalam penelitian ini adalah Apakah kualitas layanan berupa professionalism and skills, attitudes and behavior, accessibility and flexibility reliability and trustworthiness, recovery serta reputation and credibilty, berpengaruh positif dan signifikan terhadap kepuasan pelanggang Hotel Asyra Makassar.

\section{TELAAH LITERATUR DAN PENGEMBANGAN HIPOTESIS}

\section{Kualitas Layanan}

Kotler (1997: 55) mengatakan bahwa : "Quality is the totally of feature and charasteristic of a product or service that bear on its ability to satisfy stated or implied needs". Pendapat ini, memberikan penjelasan tentang kualitas yang merupakan keseluruhan karakteristik dari suatu produk dan jasa yang tercermin pada kemampuan perusahaan untuk memuaskan kebutuhan dan keinginan pelanggan.

Menurut Gronroos (dalam Jasfar, 2005: 62) mengemukakan beberapa faktor (criteria) yang menentukan kualitas jasa/layanan. Kriteria ini dapat dijadikan pegangan bagi para penyedia jasa/layanan untuk menyusun strategi agar peralatan yang dipakai maupun staf yang langsung maupun tidak langsung menghadapi konsumen dipersiapakan untuk dapat memenuhi apa yang diharapkan konsumen. Kriteria-kriteria tersebut adalah sebagai berikut :
1. Professionalism and skills ; Konsumen menghendaki agar penyedia jasa, apakah kontak personel, sistem operasi, maupun peralatan-peralatan teknik yang dimiliki haruslah dapat mengatasi masalah yang dihadapinya secara profesional dan terampil;

2. Attitudes and behavior ; Konsumen harus merasa yakin bahwa kontak personel (contact personnel) melayani dan berusaha membantu dalam memecahkan masalah mereka secara spontan dan dengan cara bersahabat;

3. Accessibility and flexibility ; Konsumen merasa bahwa penyedia jasa, apakah personel, lokasi di mana mereka berada, jam kerja dan sistem operasi dirancang serta dioperasikan sedemikan rupa, sehingga konsumen dapat melakukan akses dengan mudah, permintaan dapat disesuaikan dengan keinginan konsumen dengan cara yang lebih fleksibel;

4. Reliability and trustworthiness; Konsumen memahami bahwa apa pun yang terjadi, mereka bisa mempercayakan segala sesuatunya kepada penyedia jasa, baik kepada karyawan maupun sistemnya untuk memegang janjinya;

5. Recovery; Konsumen menyadari bahwa apa pun kesalahankesalahan yang terjadi maupun sesuatu yang tidak diduga dan yang tidak diharapkan terjadi, mereka yakin penyedia jasa akan dapat mengatasinya dengan cepat, sesuai dengan harapan mereka;

6. Reputation and credibility ; Konsumen percaya bahwa operasi atau cara kerja penyedia jasa dapat dipercaya dan memberikan nilai atau imbalan 
yang sesuai dengan
pengorbanannya.

\section{Kepuasan Pelanggang}

Kepuasan konsumen/pelanggan telah menjadi konsep sentral dalam teori dan praktek pemasaran, serta merupakan esensial bagi aktivitas bisnis (Tjiptono, 2005: 192). Kepuasan konsumen berkontribusi pada sejumlah aspek krusial, seperti terciptanya loyalitas konsumen, meningkatnya reputasi perusahaan, berkurangnya elastisitas harga, berkurangnya biaya transaksi masa depan, dan meningkatnya efisiensi dan produktivitas karyawan (Anderson dalam Tjiptono, 2005: 348-349).

\section{Kerangka Pikir}

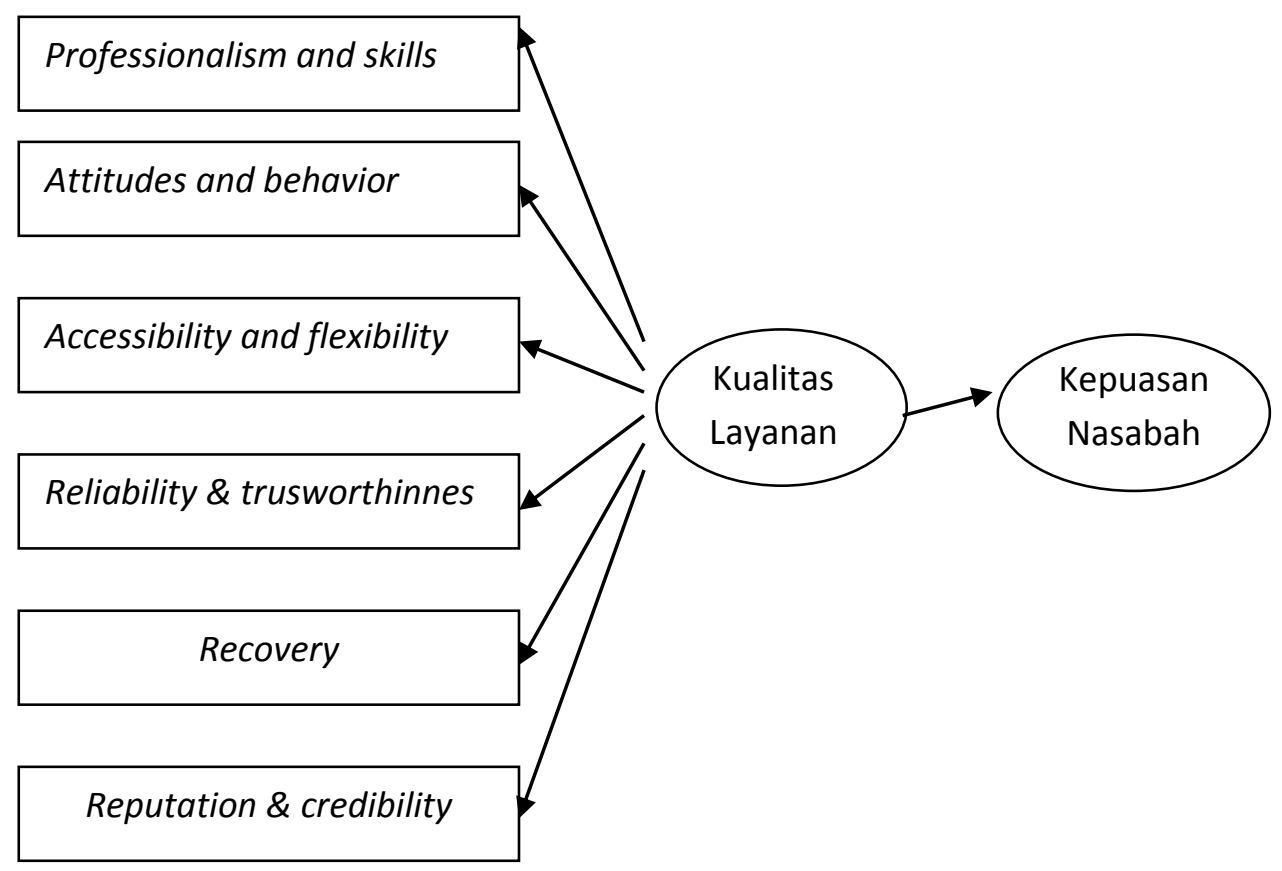

Gambar 1 Kerangka Pikir

METODE PENELITIAN

\section{Tempat dan Waktu Penelitian}

Penelitian ini dilakukan di Hotel Asyra Makassar pada bulan Mei 2019.

\section{Jenis Penelitian}

Jenis penelitian yang digunakan adalah penelitian deskriptif kausalitas dengan menggunakan metode survey sebagai cara pengumpulan informasi secara sistematik yang dilakukan terhadap responden dengan maksud untuk memahami dan atau meramal beberapa aspek yang diamati dari responden (Rangkuti, 2007: 20). Metode survey lebih memperhatikan pada sampling, desain kuesioner, pengadministrasian kuesioner dan analisis data. Responden diberi pertanyaan yang berkaitan dengan kualitas layanan Hotel Asyra Makassar dan kepuasan serta kepercayaan pelanggang pada Hotel Asyra tersebut.

\section{Populasi}

Populasi adalah wilayah generalisasi yang terdiri atas obyek/subyek yang mempunyai kualitas dan karakteristik tertentu yang ditetapkan oleh peneliti untuk 
dipelajari dan kemudian ditarik kesimpulannya (Sugiyono, 2008: 115)

\section{Sampel}

Sampel adalah bagian dari jumlah dan karakteristik yang dimiliki oleh populasi (Sugiyono, 2008: 116). Karena populasi dalam penelitian ini cukup besar sehingga akan memakan waktu, biaya dan tenaga yang cukup besar, maka peneliti akan mengambil sampel secara insidental..

Sampel penelitian ini adalah pelanggang yang inap di Hotel Asyra selama bulan Mei 2019, sehingga didapatkan sampel sebanyak 180 orang pelanggang.

\section{Jenis dan Sumber Data}

Jenis data yang digunakan dalam penelitian ini secara umum dapat dibagi ke dalam dua bagian yaitu

1. Data Primer, yaitu data yang diperoleh secara langsung dari lokasi penelitian, meliputi hasil tanggapan pelanggang atas kuesioner yang diedarkan serta hasil wawancara langsung dengan pelanggang Hotel Asyra Makassar.

2. Data sekunder, adalah data pendukung yang diperoleh dari Hotel Asyra Makassar berupa data tertulis atau dokumen tertulis seperti sejarah singkat perusahaan, data pelanggan (nasabah) dan struktur organisasi perusahaan sehingga diperoleh data yang diperlukan sehubungan dengan penelitian ini.

\section{Metode Pengumpulan Data}

Untuk memperoleh data yang dibutuhkan dalam penelitian ini, penulis menggunakan beberapa metode pengumpulan data sebagai berikut :

1. Kuesioner, yaitu metode pengumpulan data dengan cara mengedarkan daftar pertanyaan terstruktur yang ditujukan kepada pelanggang untuk memperoleh tanggapan atas kualitas layanan
Hotel Asyra Makassar pertanyaan dibuat berdasarkan jumlah variabel yang diteliti;

2. Wawancara, yaitu metode yang dilakukan dengan melakukan wawancara atau tanya jawab secara langsung kepada para pelanggang dan pimpinan serta para karyawan Hotel Asyra Makassar guna memperoleh data yang relevan. Materi wawancara adalah seputar sikap responden sehubungan dengan pengaruh kualitas layanan terhadap kepuasan pelanggang;

3. Observasi, yaitu metode pengumpulan data yang dilakukan dengan cara pengamatan secara langsung terhadap pelayanan para karyawan Hotel Asyra terhadap Pelanggang;

4. Dokumentasi, adalah dengan melakukan pengumpulan dokumentasi perusahaan untuk melengkapi data primer.

5. Studi Literatur, yaitu proses pengumpulan data yang dilakukan dengan mempergunakan rujukan ilmiah atau referensi lainnya yang relevan dengan objek penelitian sebagai data sekunder.

\section{Teknik Analisis Data}

\section{Analisis Kualitatif}

Analisis kualitatif merupakan analisis data yang dilakukan dengan cara mengumpulkan, membandingkan, menganalisis data berupa tabel-tabel dan grafik, profil responden yang dianalisis dengan cara mentabulasikan data yang diperoleh dengan prosentase serta menjelaskan mengenai kualitas layanan yang mempengaruhi kepusan dan kepercayaan nasabah.

\section{Analisis Kuantitatif}

Analisis kuantitatif merupakan metode analisis data yang dilakukan dengan cara melihat asumsi Structural 
Equation Modeling (SEM) serta uji kesesuaian dan uji statistik.

Structural Equation Modeling, memungkinkan untuk menguji beberapa variabel dependen sekaligus dengan beberapa variabel independen. Keungggulan model ini dalam penelitian manajemen adalah kemampuannya untuk menginformasikan variabel atau faktor dari konsep melalui indikator-indikator yang secara teori ada.

Adapun formulasinya adalah sebagai berikut :

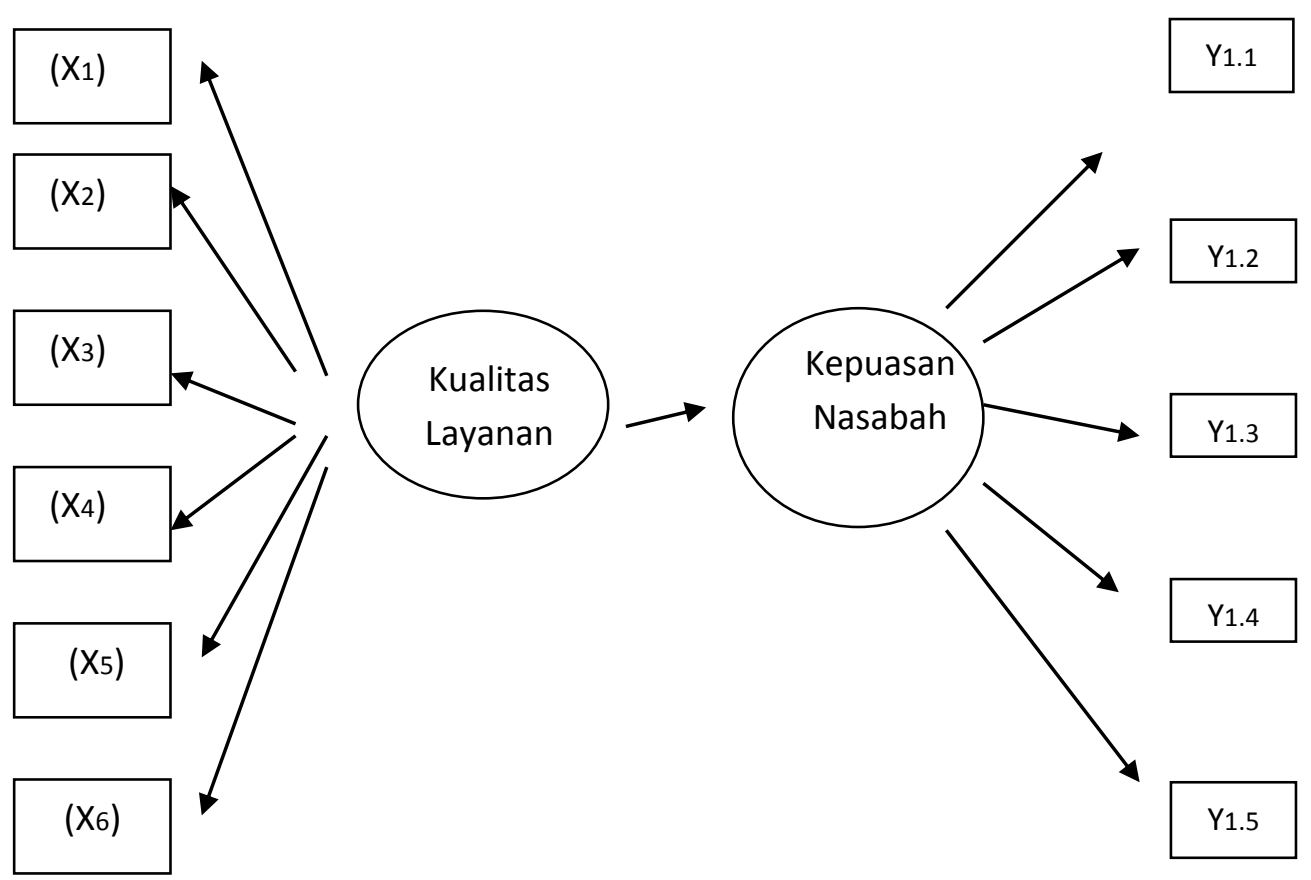

Gambar 2 Alur Kerangka Pikir Penelitian

\section{HASIL PENELITIAN DAN PEMBAHASAN}

\section{Hasil Penelitian}

\section{Karakteristik Responden}

Profil responden merupakan gambaran tentang keadaan responden yang diambil dalam penelitian. Penelitian ini difokuskan kepada pelanggang Hotel Asyra Makassar. Sedangkan sampel yaitu sejumlah 180 responden, dimana keragaman karakteristik yang ada terutama dilihat dari perbedaan jenis kelamin, perbedaan usia, jenis pekerjaan, tingkat pendidikan, dan tingkat pendapatan . Perusahaan harus mampu memahami karaktertistik responden dalam upaya mewujudkan startegi pemasaran ke depan, karena pada situasi seperti ini perusahaan akan mampu memilah, mana pelanggang yang potensial dan mana yang tidak potensial. Profil responden dapat dilihat pada tabel 1 di bawah ini: 
Tabel 1 Profil Responden Penelitian

\begin{tabular}{|l|l|c|c|}
\hline N0 & \multicolumn{1}{|c|}{ Uraian } & Frekuensi & Persentase \\
\hline 1 & Jenis Kelamin & 99 & \\
& - Laki-laki & 81 & 55,0 \\
& - Perempuan & & 45,0 \\
\hline 2 & Usia & 3 & 1,6 \\
& - 20 - 30 Tahun & 72 & 40,0 \\
& - 31 - 40 Tahun & 81 & 45,0 \\
& - 41 - 50 Tahun & 24 & 13,4 \\
& - 51 - 60 Tahun & & \\
& & 92 & 51,1 \\
3 & Pekerjaan & 29 & 15,4 \\
& - Peg. Neg, Guru, Dosen & 30 & 16,0 \\
& - Peg. BUMN/ Swasta & 8 & 4,3 \\
& - Pedagang/ Pengusaha & 21 & 11,2 \\
& - TNI/ Polri & 1 & 0,5 \\
& - Lainnya & 2 & 1,1 \\
\hline 4 & Pendidikan & 5 & 2,8 \\
& - Tidak Tamat SD & 65 & 36,1 \\
& - Tamat SD & 99 & 55,0 \\
& - Tamat SLTP & 8 & 4,5 \\
& - Tamat SLTA & \\
& - Sarjana & 16 & 8,9 \\
& - Master/Doktor & 93 & 51,7 \\
\hline 5 & Pendapatan Perbulan & 63 & 35,0 \\
& - R Rp. 2.500.000 & 6 & 1,1 \\
& - Rp. 2.501.000-5.000.000 & 2 & \\
& - Rp. 5.001.000-7.500.000 & & \\
& - Rp. 7.501.000-10.000.000 & & \\
& - > 10.000.000 & & \\
\hline
\end{tabular}

Sumber : Hasil olah data, 2019

\section{1) Profil Responden berdasarkan Jenis Kelamin.}

Profil responden berdasarkan jenis kelamin sesuai data pada Tabel 1 , dapat dilihat responden dengan jenis kelamin laki-laki 99 orang $(55,0 \%)$, sedangkan responden perempuan 81 orang $(45,0 \%)$. Berdasarkan data tersebut, menunjukkan bahwa laki-laki masih mendominasi pelanggang di Hotel Asyra.

\section{2) Profil Responden berdasarkan Usia}

Pengelompokkan responden berdasarkan usia seperti yang terlihat pada Tabel 1 menunjukkan bahwa responden yang berada pada usia 4150 tahun menempati urutan pertama yaitu 81 orang $(45,0 \%)$, kemudian disusul dengan usia 31-40 tahun sebanyak 72 orang $(40,0 \%)$. Usia 5160 tahun menempati urutan ketiga yaitu 24 orang $(13,4 \%)$. Sedangkan usia 20-30 tahun hanya 3 orang (1,6 $\%)$. Hal ini menunjukkan bahwa kebanyakan pelanggang yang inap di Hotel Asyra usia di atas 35 tahun, karena pada usia ini seseorang mobilitasnya tinggi dan memasuki usia mapan baik dari segi pendapatan/ekonomi.

Usia di bawah 30 tahun masih sangat sedikit dikarenakan pada saat itu seseorang baru mulai bekerja dan tentunya mobilitasnya juga masih rendah. Sementara untuk usia di atas 51 tahun juga sudah mulai berkurang karena saat itu seseorang sudah mulai 
memasuki usia pensiun dan sudah tentu mobilitas mulai berkurang.

\section{3) Profil Responden Berdasarkan Pekerjaan}

Tabel 4, menunjukkan bahwa responden berdasarkan pekerjaan terbesar adalah pegawai negeri, guru dan dosen yaitu sebanyak 92 orang $(51,1 \%)$. Selanjutnya disusul pedagang/pengusaha sebesar 30 orang $(16,0 \%)$, pegawai BUMN/swasta sebanyak 29 orang $(15,4 \%)$, profesi lainnya sebanyak 21 orang $\quad(11,2 \%)$ dan sisanya adalah TNI/Polri sebanyak 8 orang $(4,3 \%)$. Hal ini dapat dilihat bahwa pegawai negeri, guru dan dosen mendominasi jumlah pelanggang Hotel asyra, ini disebabkan karena pihak Manajemen melakukankerja sama dengan Pemerintah daerah dalam melakukan kegiatan-kegiatan seminar dan lain sebagainya.

\section{4) Profil Responden Berdasarkan Pendidikan}

Karakteristik responden berdasarkan tingkat pendidikan seperti pada Tabel 1, yang terbanyak adalah responden dengan tingkat pendidikan sarjana yaitu 99 orang $(55,0 \%)$, selanjutnya tingkat pendidikan SLTA 65 orang (36,1 \%), tingkat pendidikan SLTP 5 orang $(2,8 \%)$, tingkat pendidikan Master/doktor 8 orang $(4,5 \%)$ tingkat pendidikan SD 2 orang $(1,1 \%)$ dan terakhir tidak tamat SD hanya 1 orang $(0,5 \%)$. Sesuai dengan data pada Tabel 4, tersebut kebanyakan pelanggang berpendidikan sarjana, hal ini menunjukkan bahwa pelanggang yang berpendidikan tinggi banyak melakukan kegiatan di Hotel Asyra berupa seminar, kunjungan kerja dan lain sebagainya.

\section{5) Profil Responden Berdasarkan Pendapatan Per Bulan.}

Tabel 1, menunjukkan bahwa responden berdasarkan pendapatan per bulan,kebanyakan berpendapatan/berpenghasilan antara Rp 2.500.001 - Rp 5.000.000 yaitu sebesar 93 orang $(51,7 \%)$, yang berpendapatan antara Rp 5.000.001 Rp 7.500.000 sebanyak 63 orang $(35,1$ $\%)$, selanjutnya yang berpendapatan kurang dari Rp 2.500.000,sebanyak 16 orang $(8,9 \%)$, pendapatan antara Rp 7.500.001 - Rp 10.000.000 sejumlah 6 orang $(3,3 \%)$, sedangkan yang berpendapatan di atas $\mathrm{Rp}$ 10.000.000,- hanya 2 orang $(1,1 \%)$. Hal ini berarti bahwa pelanggang Hotel Asyra Makassar saat ini masih sebagian besar berada pada golongan menengah, yakni dengan penghasilan perbulan pada umumnya berada pada level Rp 2,500.000 sampai dengan Rp 7.500.000,-

\section{Pembahasan}

\section{Kontribusi Dimensi- Dimensi pada Kualitas Layanan}

\section{a. Dimensi Reliability and Trust worthinnes}

Dimensi reliability and trustworthiness memberikan kontribusi terbesar pada kualitas layanan Hotel Asyra Makassar, hal ini ditandai dengan adanya para pelanggang yang inapnya di Hotel Asyra sudah 5 kali lebih sehingga Hotel Asyra dijadikan sebagai mitra. Pernyataan ini memberi sumbangan terbesar terhadap kualitas layanan. Hotel Asyra Makassar dalam melayani pelanggang benar-benar menganggap bahwa pelanggang adalah sebagai patner kerja sehingga kapan dan di mana pun mereka mau melayani pelanggang. Kemudian juga pernyataan perusahaan selalu memenuhi kewajibannya, serta adanya jaminan akan keamanan pelanggang. Hal ini memberi sumbangan terhadap kualitas layanan sebab dengan adanya perusahaan selalu memenuhi kewajibannya serta jaminan keamanan dana maka para pelanggan akan loyal 
untuk menggunakan jasa Hotel Asyra Makassar. Dengan demikian dapat dikatakan bahwa dimensi reliability and trustworhiness memberikan kontribusi pada kualitas layanan Hotel Asyra Makassar.

\section{b. Dimensi Professionalism and Skills Dimensi Professionalism and} skills di dalam penelitian ini merupakan pemberi kontribusi terbesar kedua pada kualitas layanan Hotel Asyra Makassar. Hal ini terlihat dengan adanya kemampuan karyawan dalam memberikan layanan yang sesuai permintaan pelanggang, artinya karyawan yang memberikan pelayanan kepada pelanggang sesuai dengan keinginan, kebutuhan dan kemampuan bayar dari pelanggang yang bersangkutan. Kemudian adanya kemampuan karyawan dalam menjelaskan hak-hak yang diperoleh selama inap di Hotel. Hal ini membuktikan bahwa Karyawan Hotel Asyra Makassar sudah professional dan terampil dalam menjalankan aktivitasnya sebab dengan kemampuan-kemampuan tersebut menjadikan kualitas layanan perusahaan dapat lebih diandalkan.

\section{c. Dimensi Recovery}

Dimensi recovery merupakan dimensi ketiga yang memberi kontribusi pada kualitas layanan Hotel Asyra Makassar. Indikator yang menunjukkan adanya kontribusi yakni terlihat pada perusahaan meminta maaf atas kesalahan yang dilakukan oleh perusahaan sendiri, misalnya hotel lambat melayanai pelanggang, dan lain-lain. Juga indikator keterlibatan manajemen dalam menangani keluhan, misalnya ada pelanggang yang komplain ke Hotel, hal ini bukan hanya karyawan yang terkait menangani permasalahan tersebut, tetapi juga manajemen turut memberi jalan keluar dari persoalan yang terjadi. Hal lain yang turut memberi kontribusi adalah jaminan perusahaan tidak akan terjadi kesalahan berulang-ulang.

\section{d. Dimensi Accessibility and Flexibility}

Dimensi ini merupakan dimensi keempat yang memberi kontribusi terhadap kualitas layanan Hotel Asyra Makassar. Indikator yang mendukung pada dimensi ini adalah kemudahan menghubungi karyawan kapan dan di mana saja, misalnya pelanggang membutuhkan sesuatu, maka nasabah dapat saja meminta kepada petugas tanpa harus menunggu karyawan dibidangnya. Artinya karyawan harus mampu menguasai bidang-bidang lain diluar tugas dan tanggung jawabnya. Kesemua ini memberi kontribusi terhadap kualitas layanan Hotel Asyra Makassar.

\section{e. Dimensi Reputation and Kredibility \\ Dimensi ini merupakan dimensi} kelima yang memberikan kontribusi terhadap kualitas layanan Hotel Asyra Makassar. Indikator yang dapat dilihat kontribusinya adalah kemampuan Hotel Asyra Makassar dalam menangani keluhan pelanggang, misalnya jika ada pelanggang yang mengeluh atas tindakan karyawan yang kurang maksimal dalam melayani pelanggang, maka pihak manajerial segera memberi jaminan ke pelanggang bahwa kasus itu akan diselesaikan oleh perusahaan.

\section{f. Dimensi Attitudes and Behavior}

Dimensi attitudes and behavior ini merupakan dimensi yang paling kecil kontribusinya pada kualitas layanan Hotel Asyra Makassar. Dimensi ini memberikan kontribusi antara lain keramahan karyawan dalam melayani pelanggang, misalnya menegur pelanggang lebih awal, melayani dengan baik, ramah, dan berusaha membuat suasana menjadi bersahabat. Indikator lain yang memberi kontribusi adalah kesiapan

(C) 2019 STIE TDN. All rights reserved 
petugas menganggap pelanggang sebagai keluarga, misalnya pada melayani pelanggang, maka karyawan melakukan secara kekeluargaan. Halhal di atas menunjukkan bahwa dimensi attitudes and behavior memberi kontribusi pada kualitas layanan Hotel Asyra Makassar walaupun kontribusi dimensi ini sangat kecil dibandingkan dengan dimensidimensi lainnya. Dengan demikian maka perusahaan harus meningkatkan pembinaan kepada karyawan khususnya dalam hal menyangkut peningkatan pola sikap dan perilaku yang lebih baik lagi.

\section{Pengaruh Kualitas Layanan terhadap Kepuasan Pelanggang}

Berdasarkan hasil penelitian diketahui bahwa kualitas layanan yang secara berurutan berdasarkan tingkat signifikansinya terdiri dari reliability and trustworthiness, reputation and credibility, recovery, accessibility and flexibility, professionalism and skills, serta attitudes and behavior, berpengaruh signifikan positif sebesar 0,000 terhadap kepuasan nasabah. Hal ini ditunjang dengan adanya dimensi yang memberi kontribusi terbesar terhadap kualitas layanan Hotel Asyra Makassar yaitu dimensi reliability and trustworthiness. Dimensi ini ditunjang dengan adanya indikator terbesar yaitu menjadikan nasabah sebagai mitra. Contoh yang dapat kita lihat misalnya perusahaan selalu memperhatikan kebutuhan-kebutuhan pelanggang antara lain pelayanan yang cepat dan tepat.

Dengan adanya dimensi ini memberikan kontribusi yang terbesar terhadap kualitas layanan, maka sangat memungkinkan kualitas layanan Hotel Asyra Makassar mempunyai pengaruh terhadap kepuasan pelanggang. Sebagaimana diketahui bahwa reliability and trustworthiness mengartikan bahwa apa pun yang terjadi, pelanggang bisa mempercayakan segala sesuatunya kepada penyedia jasa, baik kepada karyawan maupun sistemnya untuk memegang janjinya. Tentu hal ini sudah merupakan sesuatu yang harus dilaksanakan oleh perusahaan untuk menjaga kualitas layanan yang dibangun kepada pelanggang.

Adapun indikator yang memberikan kontribusi terhadap dimensi reliability and trustworthiness adalah perusahaan selalu memenuhi kewajibannya, hal ini memang sejalan dengan dimensi di atas bahwa untuk meningkatkan kualitas layanan maka perusahaan harus selalu memenuhi kewajiban kepada pelanggang, misalnya dalam menyiapkan makan pagi.

Sementara dimensi yang terkecil kontribusinya terhadap kualitas layanan adalah dimensi attitudes and behavior, hal ini berarti bahwa sikap dan perilaku para karyawan masih perlu ditingkatkan, karena menyangkut sikap dan perilaku sangat penting dalam pembentukan kualitas layanan sebuah perusahaan jasa. Adapun indikator yang membentuk dimensi attitudes and behavior adalah keramahan karyawan dalam melayani pelanggang, misalnya melayani dengan penuh perhatian, memberi penjelasan dengan kalimat-kalimat yang mudah dipahami dan tidak berbelit-belit, serta melayani dengan penuh sikap persahabatan dan kekeluargaan. Halhal seperti ini masih perlu peningkatan terhadap karyawan sehingga dalam melayani pelanggang mereka harus betul-betul memberikan perhatian yang sungguh-sunguh.

Indikator lain yang memberi kontribusi terhadap dimensi attitudes and behavior sehingga membentuk kualitas layanan adalah kesiapan karyawan menganggap pelanggang sebagai keluarga. Hal ini terlihat pada kesiapan para karyawan membantu 
pelanggang secara kekeluargaan. walupun pelanggang meminta untuk diuruskan, misalnya menjemput dari bandara atau sebaliknya dengan mempergunakan mobil perusahaan.

Dengan adanya perlakuanperlakuan seperti itu, maka nasabah merasa sangat puas karena mereka menganggap kualitas layanan yang terbentuk dari perusahaan dapat memberi kepuasan terhadap apa yang mereka harapkan. Dengan demikian maka dimensi-dimensi tersebut membentuk kualitas layanan Hotel Asyra Makassar yang mempunyai pengaruh terhadap kepuasan nasabah, karena dimensi tersebut satu dengan yang lain saling menopang untuk menciptakan kualitas layanan yang nantinya berpengaruh terhadap kepuasan pelanggang.

\section{KESIMPULAN}

\section{Kesimpulan}

1.Keenam dimensi memberi kontribusi pada kualitas layanan Hotel Asyra Makassar, yang terbesar kontibusinya adalah dimensi reliability and trustworthiness, terutama indikator menjadikan pelanggang sebagai mitra dan indikator perusahaan selalu memenuhi kewajibannya. Sedangkan yang paling kecil adalah attitudes and behavior.;

2. Kualitas layanan berpengaruh positif dan signifikan terhadap kepuasan nasabah Hotel Asyra Makassar, dan kontribusi terbesar adalah reliability and trustworthiness;

\section{Saran}

1. Kualitas layanan yang dilakukan oleh Hotel Asyra Makassar pada umumnya sudah baik, sehingga perlu dipertahankan;

2. Dimensi kualitas layanan yang masih lemah seperti attitude and behavior perlu diperhatikan oleh perusahaan sehingga ke depan masalah sikap dan perilaku karyawan dapat lebih dtingkatkan;

3. Perlu menjalin hubungan dengan berbagai pihak sehingga Hotel Asyra Makassar lebih dikenal di masyarakat yang pada akhirnya akan menambah kepercayan masyarakat terhadap jasa asuransi tersebut;

4. Perlu peningkatan kualitas sumber daya manusia bagi para karyawan dengan melakukan pelatihanpelatihan secara internsif dan secara berkesinambungan.

\section{DAFTAR PUSTAKA}

Arbuckle, J.1. \& Wothke, W, 1999. Amos, 4,0 User's Guide : SPSS, Smallwaters Corporation

Ferdinand, Augusty, 2002. Struktural Equation Modeling Dalam Penelitian Manajemen, BP Undip, Fakultas Ekonomi Universitas Diponegoro Semarang

Jasfar, Farida, 2005. Manajemen Jasa, Edisi Pertama. Penerbit Ghalia Indonesia, Ciawi Bogor

Kotler, Philip and Lane K. Keller, $2006 . \quad$ Manajemen Pemasaran, Jilid 1 dan 2, Edisi 12, PT. Macanan Jaya Cemerlang.

Malhotra, Naresh K, 2005. Riset Pemasaran : Pendekatan dan Terapan, Edisi Bahasa Indonesia, PT. Indeks Kelompok Gramedia, Jakarta.

Rangkuti, Freddy, 2006. Measuring Customer Satisfaction Teknik Mengukur dan Strategi Meningkatkan Kepuasan Pelanggan plus Analisis Kasus PLN - JP. 
Cetakan ketiga. Penerbit PT. Gramedia Pustaka Utama, Jakarta.

J----- 2007. Riset Pemasaran,

Edisi kedelapan. Penerbit

PT. Gramedia Pustaka

Utama, Jakarta.

Simamora, Andreas, 2004. Uji Instrumen Penelitian Sosial. Penerbit Ghalia, Jakarta.

Sugiyono, 2008. Metode Penelitian Bisnis, Edisi kesebelas. Penerbit Alfabeta Bandung.

Sugiyono, 2008. Statistika Untuk Penelitian, Edisi ketigabelas. Penerbit Alfabeta Bandung.

Suparmono dan Jony Oktavian Haryanto, 2005. Desain Proposal Penelitian Studi Pemasaran, ANDI, Yogyakarta.

Tjiptono, Fandy, 2005. Pemasaran Jasa, Edisi pertama. Penerbit Bayumedia, Malang Jawa Timur.

--------- 2007. Pemasaran Jasa, Edisi ketiga. Penerbit Bayumedia, Malang Jawa Timur.

Tjiptono, Fandy dan Chandra, Gregorius, 2005. Service, Quality and Satisfaction. Yogyakarta Andi. 